\title{
EFFECT OF PARTICLE SIZES AND CONTENT OF ORGANIC MATTER SEDIMENT ON EPIPELIC DIATOM ABUNDANCE IN BAYUR BAY WATERS OF WEST SUMATERA
}

\author{
Benni Mario K. Sitindoan ${ }^{1^{*}}$, Sofyan Husein Siregar ${ }^{2}$, Irvina Nurrachmi \\ ${ }^{1}$ Student of The Faculty of Fisheries and Marine Science University of Riau, Pekanbaru \\ ${ }^{2}$ Lecturer at The Faculty of Fisheries and Marine Science University of Riau, Pekanbaru \\ *bennimarios@gmail.com
}

\begin{abstract}
The aim of this study is to determine the water quality, the particle size (mm) and the organic matter content sediment, the type and abundance of epipelic diatoms, and the effect of particle size and organic matter content of the sediment on the abundance of epipelic diatoms at Bayur Bay Waters. This study was conducted in June - July 2019. The survey method was applied in this study and sampling location determine by purposive sampling. The resullt of measurement of water quality parameter ranged salinity $29 \%$ - $34 \%$, pH 7-8, current speed of $0,10 \mathrm{~m} / \mathrm{s}-0,53 \mathrm{~m} / \mathrm{s}$, temperature $30,33^{0} \mathrm{C}-31,67^{0} \mathrm{C}$. The sediment types are grouped into four types, namely gravel, sandy gravel, gravelly sand, and sand. The average of particle size $(\mathrm{Mz})$ ranged $-1,37 \varnothing-0,80 \varnothing$. The organic matter on sediment ranged $2,46 \%$ 6,36\%. Eleven species of epipelic diatoms was recorded namely Amphora sp, Cocconeis sp, Diploineis sp, Halamphora sp, Melosira sp, Navicula sp, Nitzschia sp, Pinnularia sp, Stephanodiscus sp, Isthmia sp and Synedra sp. The average value of abundance range 2.836 $10.812 \mathrm{ind} / \mathrm{cm}^{2}$. Epipelik diatom abundance was not significantly different between the stations. The effect of sediment particle size on the abundance of epipelic diatoms by $34,37 \%$. The effect of content of organic matter sediment on abundance of epipelic diatoms in Bayur Bay Waters by $51,78 \%$.
\end{abstract}

Keywords: The particle size of the sediment, organic matter sediments, epipelik, diatoms, Bayur Bay Water

\section{PENDAHULUAN}

Mikroalga adalah organisme mikroskopis yang hidup di permukaan, kolom air dan dasar perairan. Salah satu mikroalga yang hidup di dasar perairan adalah benthic diatom. Benthic diatom dibagi menjadi beberapa kelompok, salah satunya adalah diatom epipelik yaitu mikroalga yang hidup pada substrat sedimen yang jenis dan kelimpahannya sangat dipengaruhi oleh kualitas air dan kondisi sedimen (Supono, 2008).
Sedimen merupakan habitat bagi organisme benthos seperti diatom epipelik. Jenis sedimen berpengaruh terhadap kandungan bahan organik. Sedimen berpasir memiliki kandungan bahan organik rendah, hal ini disebabkan pada sedimen tersebut memungkinkan terjadinya oksidasi yang baik akibat adanya pore water yang lebih besar, sehingga bahan organik akan cepat habis. Sebaliknya pada jenis sedimen liat yang mempunyai tekstur 
lebih halus, kandungan bahan organik tergolong tinggi.

Penelitian ini bertujuan untuk menentukan kondisi kualitas air di perairan, mengetahui ukuran partikel sedimen (mm) dan kandungan bahan organik sedimen, mengetahui jenis dan kelimpahan diatom epipelik, mengetahui pengaruh ukuran partikel sedimen $(\mathrm{mm})$ dan kandungan bahan organik sedimen terhadap kelimpahan diatom epipelik di perairan Teluk Bayur Sumatera Barat.

\section{METODE PENELITIAN}

Penelitian ini dilaksanakan pada bulan Juni - Juli 2019 di perairan Teluk

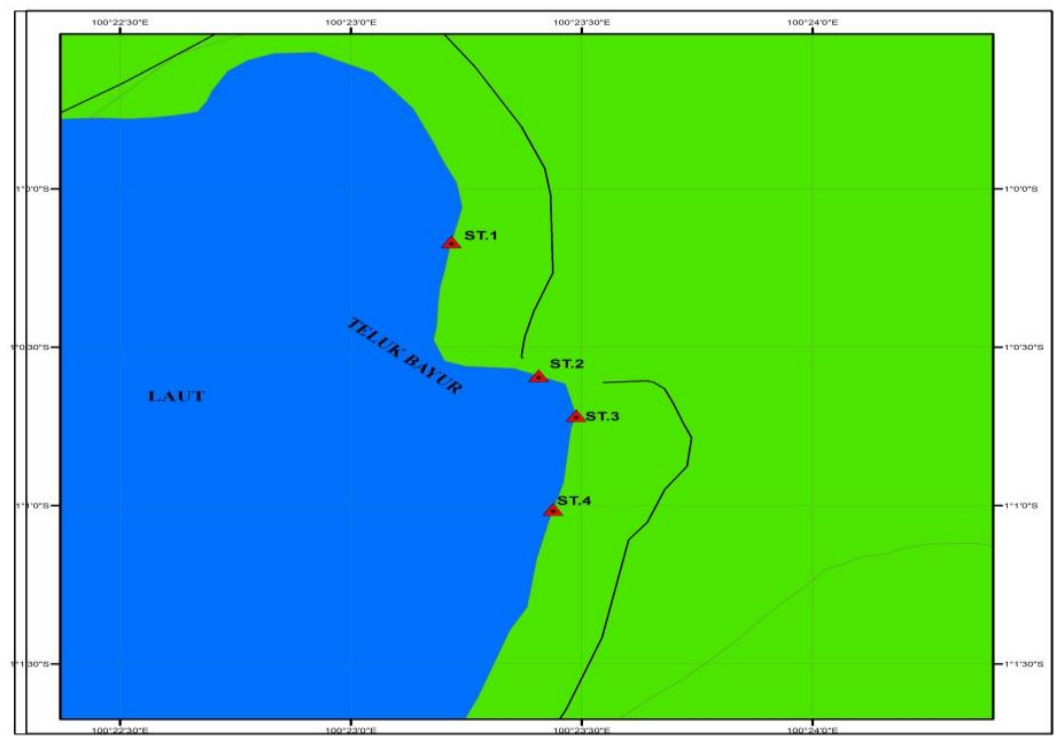

Gambar 1. Peta Lokasi Penelitian
Bayur Sumatera Barat (Gambar 1). Analisis sampel dilakukan di Laboratorium Biologi Laut dan Kimia Laut Fakultas Perikanan dan Kelautan Universitas Riau.

Metode yang digunakan dalam penelitian ini adalah metode survei, yaitu pengamatan dan pengambilan sampel langsung di lapangan. Kemudian sampel dianalisis di laboratorium, selanjutnya data yang diperoleh diolah dan disajikan dalam bentuk tabel. Kemudian dibahas secara deskriptif dengan mengacu atau merujuk pada literatur yang berkaitan dengan penelitian tersebut.

\section{Penentuan Lokasi Penelitian}

Lokasi sampling ditentukan dengan cara Purposive sampling. Lokasi Penelitian dibagi menjadi 4 stasiun yaitu: stasiun I berada dekat dengan permukiman penduduk, stasiun II berada di dermaga nelayan, stasiun III berada di Pantai Nirwana dan stasiun IV berada di daerah mangrove.

\section{Pengambilan Sampel Sedimen}

Pengambilan sampel sedimen dilakukan pada waktu surut di titik yang sama dengan pengambilan sampel diatom epipelik yakni menggunakan pipa PVC berdiameter $6 \mathrm{~cm}$ yang ditancapkan pada dasar perairan dengan kedalaman $\pm 10 \mathrm{~cm}$. lalu pipa yang telah berisi sedimen diangkat. Sedimen yang terdapat dalam pipa diambil sebanyak 500 gram lalu dimasukkan ke dalam kantong plastik kemudian diberi label sesuai dengan stasiun dan titik sampling selanjutnya sampel dimasukkan ke dalam ice box dan dibawa ke laboratorium untuk dianalisis. Sampel sedimen yang sudah diambil sebanyak 500 gram berat basah kemudian diambil 150 gram untuk analisis jenis sedimen (Rifardi, 
2008) dan 50 gram untuk analisis bahan organik (Pett, 1993).

\section{Pengambilan dan Penanganan Sampel Diatom}

Pengambilan sampel diatom epipelik mengacu pada metode yang dikembangkan oleh Siregar (1995) dimana sampel diatom diambil pada saat surut terendah dengan cara mengambil sampel permukaan sedimen dengan ketebalan $\pm 1 \mathrm{~cm}$ menggunakan spatula pada triplek yang bagian tengahnya telah dilubangi dengan ukuran $5 \mathrm{~cm}$ x $5 \mathrm{~cm}$. Pengambilan sampel diatom epipelik dilakukan 3 kali ulangan tiap stasiun, yakni upper zone, middle zone, dan lower zone. Sampel diatom epipelik dari sedimen yang telah diambil tersebut dimasukkan ke dalam botol sampel dengan volume $50 \mathrm{ml}$ dan selanjutnya diawetkan menggunakan larutan pengawet lugol 4\%, botol sampel diberi label sesuai kode pengambilan sampel kemudian disimpan dalam ice box untuk selanjutnya dianalisis di laboratorium.

\section{Karakteristik Sedimen}

Perhitungan nilai $\varnothing$ (phi) tersebut didapatkan dengan menggunakan rumus yang diperoleh dari metode grafik menurut Fork dan Ward dalam Rifardi (2001a) sebagai berikut:

$$
\text { Mean size }(\mathrm{Mz})=\frac{\emptyset 16+\varnothing 50+\varnothing 84}{3}
$$

\section{Kandungan Bahan Organik Sedimen}

Perhitungan kandungan bahan organik dilakukan dengan rumus:

$$
\text { Zat Organik Total }=\frac{a-c}{a-b} \times 100 \%
$$

Keterangan :

$$
\begin{aligned}
\mathrm{a}= & \text { berat wadah dan sampel sedimen } \\
& \text { setelah pengeringan }(\mathrm{g}) \\
\mathrm{b}= & \text { berat wadah }(\mathrm{g}) \\
\mathrm{c}= & \text { berat wadah dan sampel setelah } \\
& \text { pembakaran }(\mathrm{g})
\end{aligned}
$$

\section{Kelimpahan Diatom Epipelik}

Perhitungan kelimpahan diatom digunakan rumus modifikasi Lackey Drop Microtransecting Methods (APHA, 1995) :

$$
N=\frac{3 O i}{O p} \times \frac{V r}{3 V o} \times \frac{1}{A} \times \frac{n}{3 p}
$$

Keterangan:

$\mathrm{N}=$ Jumlah diatom per satuan luas (Ind $/ \mathrm{cm}^{2}$ )

$\mathrm{Oi}=$ Luas gelas penutup $\left(625 \mathrm{~nm}^{2}\right)$

$\mathrm{Op}=$ Luas satuan pandang $\left(1,306 \mathrm{~nm}^{2}\right)$

$\mathrm{Vr}=$ Volume konsentrat dalam botol sampel (50 ml)

Vo $=$ Volume 1 tetes sampel $(0,05 \mathrm{ml})$

$\mathrm{A}=$ Luas bidang penampang $\left(25 \mathrm{~cm}^{2}\right)$

$\mathrm{n}=$ Jumlah diatom epipelik yang terambil

$\mathrm{P} \quad=$ Jumlah lapang pandang (12)

\section{Analisis Data}

Data yang diperoleh dianalisis menggunakan Software Microsoft Excel 2010 dan Software Statistical for Social Science (SPSS), selanjutnya disajikan dalam bentuk tabel, grafik dan dibahas secara deskriptif.

\section{HASIL DAN PEMBAHASAN Kondisi Geografis}

Perairan Teluk Bayur terletak di Kecamatan Padang Selatan Kota Padang Provinsi Sumatera Barat. Teluk Bayur merupakan daerah yang ramai aktivitas seperti pelabuhan, perindustrian, pariwisata, maupun perikanan. Perairan Teluk Bayur terletak pada koordinat antara 00³8'38" LU - 01'01'05" LS dan $100^{\circ} 23^{\prime} 25^{\prime \prime}$ BT - $100^{\circ} 23^{\prime} 19^{\prime \prime}$ BT. Secara geografis, perairan Teluk Bayur berbatasan langsung dengan wilayah sebagai berikut : (a) Sebelah utara berbatasan dengan Teluk Bayur Utara, (b) Sebelah selatan berbatasan dengan Samudera Indonesia (c) Sebelah barat berbatasan dengan Samudera Indonesia, (d) Sebelah timur berbatasan dengan Kelurahan Air Manis. 


\section{Parameter Kualitas Perairan}

Parameter kualitas air yang diamati meliputi parameter fisika perairan dan kimia perairan. Untuk lebih jelasnya data parameter kualitas perairan dapat dilihat pada Tabel 1.

Tabel 1. Parameter Kualitas Perairan

\begin{tabular}{ccccc}
\hline Stasiun & Suhu $\left(\mathbf{~}^{\mathbf{0}} \mathbf{C}\right)$ & Kecepatan Arus $(\mathbf{m} / \mathbf{d e t})$ & $\mathbf{p H}$ & Salinitas $(\mathbf{0} / \mathbf{0 0})$ \\
\hline 1 & 31 & 0,13 & 7 & 29 \\
2 & 31,67 & 0,53 & 7 & 33,33 \\
3 & 30,67 & 0,16 & 7,33 & 34 \\
4 & 30,33 & 0,10 & 8 & 34 \\
\hline
\end{tabular}

\section{Fraksi Sedimen}

Berdasarkan hasil analisis sampel sedimen di Perairan Teluk Bayur, maka dapat diketahui persentase dari fraksi kerikil, pasir dan lumpur serta ukuran partikel sedimennya.

Tabel 2. Fraksi Sedimen

\begin{tabular}{cccccl}
\hline \multirow{2}{*}{ Stasiun } & Titik & \multicolumn{3}{c}{ Fraksi Sedimen (\%) } & \multirow{2}{*}{ Tipe Sedimen } \\
\cline { 2 - 5 } & Sampling & Kerikil & Pasir & Lumpur & \\
\hline \multirow{2}{*}{1} & 1.1 & 53,59 & 41,13 & 5,28 & Kerikil berpasir \\
& 1.2 & 60,76 & 35,96 & 3,28 & Kerikil berpasir \\
& 1.3 & 53,88 & 43,04 & 3,08 & Kerikil berpasir \\
\hline \multirow{2}{*}{2} & 2.1 & 58,14 & 40,42 & 1,45 & Kerikil berpasir \\
& 2.2 & 63,27 & 35,41 & 1,32 & Kerikil berpasir \\
& 2.3 & 73,56 & 25,13 & 1,31 & Kerikil berpasir \\
\hline \multirow{2}{*}{3} & 3.1 & 44,83 & 50,85 & 4,32 & Pasir berkerikil \\
& 3.2 & 53,40 & 43,99 & 2,61 & Pasir berkerikil \\
& 3.3 & 97,05 & 2,12 & 0,83 & Kerikil \\
\hline \multirow{2}{*}{4} & 4.1 & 5,71 & 91,65 & 2,64 & Pasir \\
& 4.2 & 28,66 & 69,37 & 1,96 & Kerikil berpasir \\
& 4.3 & 97,80 & 2,11 & 0,09 & Kerikil \\
\hline
\end{tabular}

Secara keseluruhan, kondisi fraksi substrat dasar perairan Teluk Bayur mengandung ukuran butiran yang kasar. Arus dan gelombang merupakan faktor utama yang menentukan arah, sebaran dan jenis sedimen, hal ini didukung oleh Nybakken (1992), menyatakan bahwa keberadaan lumpur di dasar perairan sangat dipengaruhi oleh banyaknya partikel partikel tersuspensi yang dibawa air tawar. Selanjutnya Emiyarti (2004) menyatakan bahwa karakteristik sedimen akan mempengaruhi morfologi fungsional dan tingkah laku hewan benthik, hewan benthik beradaptasi sesuai dengan tipe substratnya. Pada jenis substrat berpasir kandungan oksigen relatif besar dibandingkan dengan substrat halus, karena pada substrat berpasir terdapat pori air yang memungkinkan terjadinya pencampuran yang lebih intensif dengan air diatasnya. Akan tetapi, pada sedimen berpasir tidak banyak terdapat bahan organik. Pada substrat yang lebih halus, walaupun oksigen sangat sedikit namun ketersediaan nutrien cukup besar.

Proses pembentukan sedimen di perairan pantai selain dipengaruhi oleh gaya gelombang, juga ditentukan oleh aktivitas artifisial (manusia) yang ada di daratan. Pengaruh artificial disekitar pantai mempengaruhi sebaran fraksi sedimen karena aktivitas ini mensuplai poorly soorted sediment (Rifardi, 2008a). 


\section{Parameter Statistik Sedimen}

Hasil perhitungan parameter statistik sedimen menunjukkan karakteristik sedimen di perairan Teluk Bayur Sumatera Barat berdasarkan mean size $(\mathrm{Mz})$ yang dapat dilihat pada Tabel 3.

Tabel 3. Nilai diameter Mean Size (Mz)

\begin{tabular}{cccccl}
\hline St & $\begin{array}{c}\text { Titik } \\
\text { Sampling }\end{array}$ & $\boldsymbol{\emptyset}(\boldsymbol{p h i})$ & Mm & $\begin{array}{c}\text { Rata-rata } \\
\boldsymbol{\emptyset}\end{array}$ & Klasifikasi \\
\hline \multirow{2}{*}{1} & 1 & $-0,17$ & 1,17 & & Pasir sangat kasar \\
& 2 & $-0,30$ & 1,30 & $-0,29$ & Pasir sangat kasar \\
& 3 & $-0,40$ & 1,40 & & Pasir sangat kasar \\
\hline \multirow{2}{*}{2} & 1 & $-0,30$ & 1,30 & & Pasir sangat kasar \\
& 2 & $-0,83$ & 1,83 & $-0,68$ & Pasir sangat kasar \\
& 3 & $-0,90$ & 1,90 & & Pasir sangat kasar \\
\hline \multirow{2}{*}{3} & 1 & 0,03 & 1,01 & & Pasir kasar \\
& 2 & $-0,33$ & 1,33 & $-0,56$ & Pasir sangat kasar \\
& 3 & $-1,37$ & 2,74 & & Kerikil \\
\hline \multirow{2}{*}{4} & 1 & 0,80 & 0,40 & & Pasir kasar \\
& 2 & 0,03 & 1,30 & $-0,17$ & Pasir kasar \\
& 3 & $-1,33$ & 2,66 & & Kerikil \\
\hline
\end{tabular}

Berdasarkan hasil perhitungan nilai diameter mean size $(\mathrm{Mz})$, nilai rata - rata $\varnothing$ (phi) tertinggi terdapat di stasiun 4 yakni 0,17 dan terendah terdapat di stasiun 3 yakni $-0,68$. Terdapat 4 (empat) klasifikasi nilai diameter mean size $(\mathrm{Mz})$ di perairan Teluk Bayur Sumatera Barat, yakni kerikil, pasir sangat kasar, pasir kasar, dan pasir.

Ukuran butiran sedimen di perairan Teluk Bayur yang kasar ini juga disebabkan oleh kondisi arus perairan yang cenderung kuat. Hal ini sesuai dengan pendapat Nugroho (2014), adanya sedimen halus diendapkan pada arus dan gelombang yang benar-benar tenang, sedangkan sedimen berukuran kasar menunjukkan bahwa arus dan gelombang pada daerah itu relatif kuat, fraksi kasar umumnya diendapkan pada daerah terbuka yang berhubungan dengan laut lepas.Kecepatan arus (aliran transport) mempunyai pengaruh yang lebih besar pada pola kelas ukuran sedimen, selain salinitas yang lebih didukung oleh pendapat Rifardi (2008b) yang menyatakan bahwa beragamnya distribusi diameter rata-rata $(\mathrm{Mz})$ dan kandungan lumpur menunjukkan bahwa distribusi sangat dipengaruhi dengan sistem arus pasang surut. Gelombang dan arus merupakan dua faktor yang mempengaruhi jenis ukuran sedimen.

Perbedaan ukuran partikel sedimen pada dasar perairan dipengaruhi juga oleh perbedaan jarak dari sumber sedimen tersebut. Secara umum, partikel berukuran kasar akan diendapkan pada lokasi yang tidak jauh dari sumbernya. Sebaliknya semakin halus partikel akan semakin jauh ditransportasikan oleh arus dan gelombang, dan semakin jauh diendapkan dari sumbernya.

\section{Bahan Organik Sedimen}

Hasil analisis bahan organik sedimen di perairan Teluk Bayur Sumatera Barat dapat dilihat pada Tabel 4 . 
Tabel 4. Bahan Organik Sedimen

\begin{tabular}{|c|c|c|c|c|c|c|}
\hline \multirow[b]{2}{*}{ ST } & \multirow[b]{2}{*}{$\begin{array}{c}\text { Titik } \\
\text { Sampling }\end{array}$} & \multicolumn{3}{|c|}{ Hasil Perhitungan } & \multirow{2}{*}{$\begin{array}{l}\text { Nilai Bahan } \\
\text { Organik } \\
(\%)\end{array}$} & \multirow{2}{*}{$\begin{array}{l}\text { Nilai Bahan } \\
\text { Organik }(\%) \\
\pm \quad \text { Standar } \\
\text { Deviasi }\end{array}$} \\
\hline & & $\mathbf{A}(\mathbf{g})$ & B (g) & $\mathrm{C}(\mathrm{g})$ & & \\
\hline \multirow{3}{*}{1} & 1.1 & 40,63 & 1,39 & 38,15 & 6,32 & \multirow{3}{*}{$5,16 \pm 1,07$} \\
\hline & 1.2 & 41,43 & 1,44 & 39,75 & 4,20 & \\
\hline & 1.3 & 40,09 & 1,39 & 38,17 & 4,96 & \\
\hline \multirow{3}{*}{2} & 2.1 & 38,99 & 1,34 & 37,58 & 3,75 & \multirow{3}{*}{$3,20 \pm 0,67$} \\
\hline & 2.2 & 39,14 & 1,39 & 37,86 & 3,39 & \\
\hline & 2.3 & 42,32 & 1,30 & 41,31 & 2,46 & \\
\hline \multirow{3}{*}{3} & 3.1 & 40,44 & 1,34 & 38,89 & 3,96 & \multirow{3}{*}{$4,19 \pm 0,22$} \\
\hline & 3.2 & 38,71 & 1,35 & 37,14 & 4,20 & \\
\hline & 3.3 & 39,85 & 1,48 & 38,16 & 4,40 & \\
\hline \multirow{3}{*}{4} & 4.1 & 39,85 & 1,48 & 37,41 & 6,36 & \multirow{3}{*}{$5,85 \pm 0,62$} \\
\hline & 4.2 & 41,96 & 1,41 & 39,87 & 5,15 & \\
\hline & 4.3 & 37,69 & 1,33 & 35,50 & 6,02 & \\
\hline
\end{tabular}

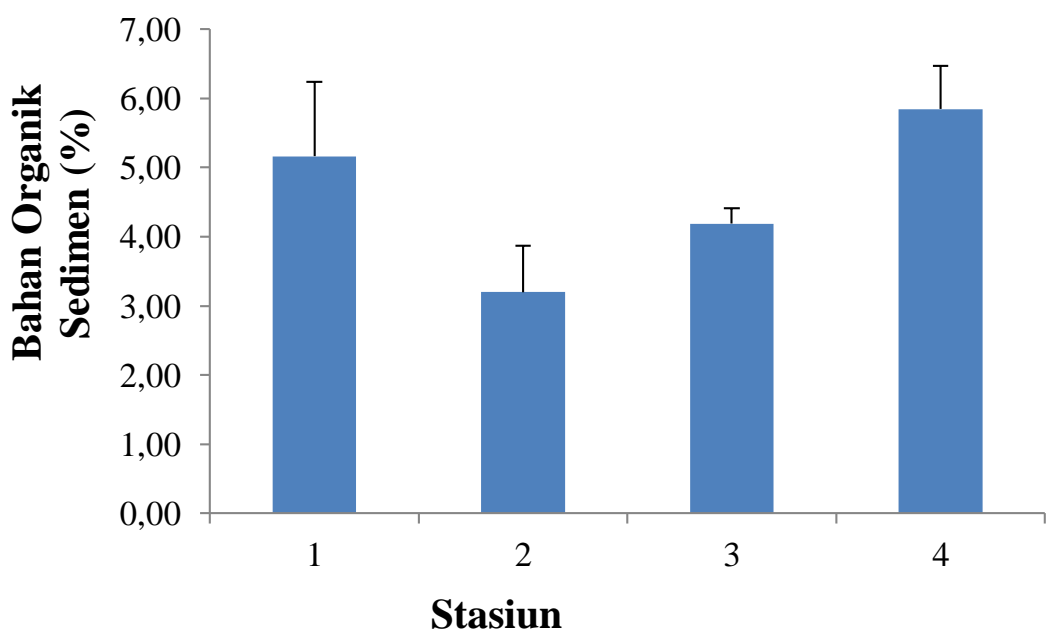

Gambar 2. Bahan Organik Sedimen

Hasil pengukuran bahan organik sedimen setiap stasiun menunjukkan ratarata kandungan bahan organik sedimen tertinggi berada pada stasiun 4 titik sampling 1 yaitu $6,36 \%$, sedangkan kandungan bahan organik sedimen terendah berada pada stasiun 2 titik sampling 3 yaitu $2,46 \%$. Rendahnya bahan organik ini disebabkan oleh tingginya kandungan fraksi kerikil berpasir yang mendominasi di perairan Teluk Bayur. Keadaan ini sesuai dengan (Clark dalam Ardi, 2002), bahwa sedimen berpasir memiliki kandungan bahan organik lebih sedikit dibandingkan dengan sedimen lumpur. Kemampuan lumpur menyimpan bahan organik lebih besar daripada pasir dikarenakan substrat lumpur memiliki pori-pori yang lebih rapat sehingga bahan organik lebih mudah mengendap dibandingkan substrat pasir yang partikel dan pori-porinya lebih besar yang menyebabkan bahan organik mudah terbawa arus.

Kadar bahan organik dalam suatu sedimen sangat berhubungan dengan jenis fraksi sedimen pada suatu perairan. Semakin tinggi kandungan fraksi lumpur/lempung dan liat dalam sedimen yang diperoleh, maka kandungan bahan organik semakin tinggi. Sebaliknya, 
semakin rendah kandungan fraksi lumpur/lempung dan liat dalam sedimen, maka kandungan bahan organik semakin rendah. Hal ini diperkuat oleh Supriyadi (2008) dan Bengen (2002) bahwa bahan organik cenderung meningkat dengan meningkatnya kandungan lempung dan liat.
Diatom Epipelik

Klasifikasi Diatom Epipelik di Perairan Teluk Bayur

Berdasarkan hasil dari pengamatan yang telah dilakukan, ditemukan beberapa jenis diatom epipelik di perairan Teluk Bayur. Jenis -jenis diatom epipelik yang teramati disajikan di Tabel 5

\section{Tabel 5. Klasifikasi Diatom Epipelik}

\begin{tabular}{llll}
\hline No & Ordo & Famili & Genus/Jenis \\
\hline 1 & Thalassiophysales & Catenulaceae & Amphora $\mathrm{sp}$ \\
2 & Achnanthales & Cocconeidaceae & Cocconeis $\mathrm{sp}$ \\
3 & Naviculales & Diploneidaceae & Diploineis $\mathrm{sp}$ \\
4 & Thallassiophysales & Catenulaceae & Halamphora sp \\
5 & Centrales & Coscinodiscaceae & Melosira sp \\
6 & Naviculales & Naviculaceae & Navicula sp \\
7 & Bacillariales & Bacillariaceae & Nitzschia sp \\
8 & Naviculales & Pinnulariaceae & Pinnularia sp \\
9 & Thallassiosirales & Stephanodiscaceae & Stephanodiscus sp \\
10 & Hemiaulales & Hemiaulaceae & Isthmia sp \\
11 & Fragilariales & Fragilariaceae & Synedra sp \\
\hline
\end{tabular}

Klasifikasi diatom epipelik seluruhnya yang ditemukan dari kelas Bacillariophyceae terdiri atas 11 genus

Kelimpahan Diatom Epipelik di Perairan Teluk Bayur
Berdasarkan hasil penelitian yang dilakukan ditemukan kelimpahan yang berbeda-beda pada tiap stasiun penelitian. Perhitungan kelimpahan diatom lebih jelasnya dapat dilihat pada Tabel 6 .

Tabel 6. Kelimpahan Diatom Epipelik di Perairan Teluk Bayur

\begin{tabular}{cccc}
\hline Stasiun & Titik Sampling & $\begin{array}{c}\text { Kelimpahan } \\
\left(\mathbf{I n d} / \mathbf{c m}^{2}\right)\end{array}$ & $\begin{array}{c}\text { Kelimpahan Diatom }\left(\mathbf{I n d} / \mathbf{c m}^{\mathbf{2}}\right) \pm \\
\text { Standar Deviasi }\end{array}$ \\
\hline \multirow{2}{*}{1} & 1.1 & 10.812 & $7.740 \pm 2.713,25$ \\
& 1.2 & 6.735 & \\
& 1.3 & 5.672 & $5.258 \pm 1.068,38$ \\
2 & 2.1 & 5.140 & \\
& 2.2 & 6.381 & $4.254 \pm 1.278,13$ \\
3 & 2.3 & 4.254 & \\
& 3.1 & 4.608 & $8.862 \pm 2.262,91$ \\
\hline \multirow{2}{*}{4} & 3.2 & 5.317 & \\
& 3.3 & 2.836 & \\
\hline
\end{tabular}

Berdasarkan Tabel 6 kelimpahan diatom yang ditemukan dapat diperoleh nilai rata-rata kelimpahan diatom di perairan dengan nilai kelimpahan yang berbeda-beda pada setiap stasiun pengamatan. Dimana nilai kelimpahan 
berkisar $2.836-10.812 \mathrm{ind} / \mathrm{cm}^{2}$, untuk lebih jelasnya dapat dilihat pada gambar 3 .

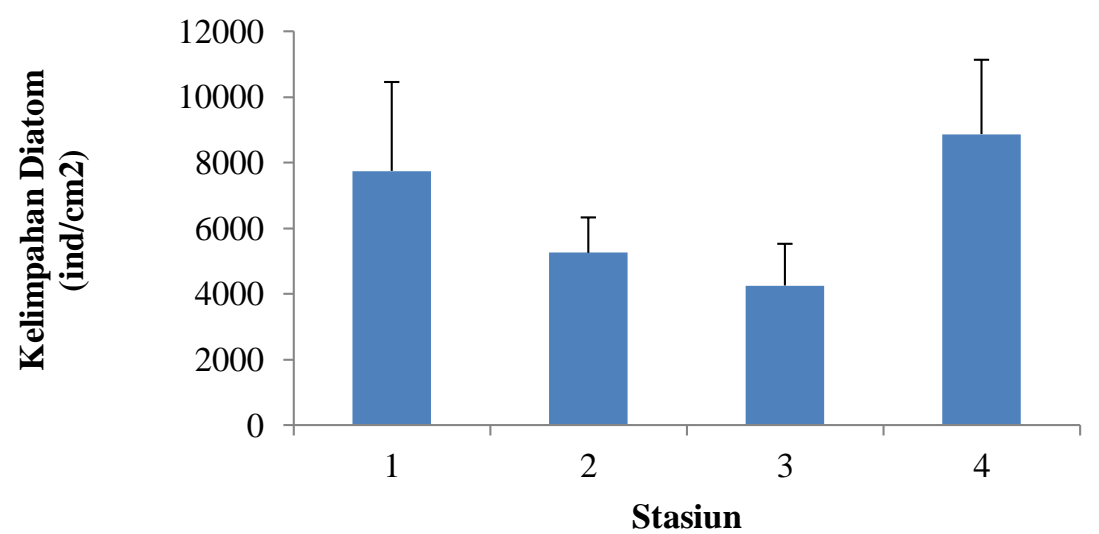

Gambar 3. Kelimpahan Diatom Epipelik Pada Masing - Masing Stasiun Pengamatan

Kelimpahan diatom epipelik yang ditemukan diperairan Teluk Bayur Sumatera Barat berdasarkan hasil pengamatan identifikasi yang telah dilakukan terdapat 11 genus yang ditemukan yaitu: Amphora, Cocconeis, Diploineis, Halamphora, Isthmia, Melosira, Navicula, Nitzschia, Pinnularia, Stephanodiscus, dan Synedra. Diatom Ordo Pennales lebih banyak ditemukan daripada diatom yang berasal dari Ordo Centrales. Menurut Suartimah, (2011), hal ini dikarenakan diatom pennales bersifat bentik atau hidup didasar perairan sedangkan diatom Centrales lebih bersifat planktonik atau hidup dengan melayang layang pada kolom - kolom air. Cahoon dan Saffi (2002) menyatakan bahwa distribusi diatom juga dipengaruhi oleh pergerakan (turbulensi) air dan pasang surut. Hal ini memberikan peluang fitoplankton yang hidup bebas dalam komunitas benthik. Pengaruh pasang surut mempengaruhi penyebaran diatom benthik. Hal ini juga dijelaskan oleh Cahoon dan Safii (2002) bahwa beberapa diatom planktonik akan bergerak ke permukaan substrat ketika kondisi surut.

Kelimpahan diatom epipelik bervariasi antara satu stasiun dengan stasiun lainnya. Kelimpahan tertinggi berada di stasiun 4, yakni pada daerah mangrove dan kelimpahan terendah berada di stasiun 3, yakni di Pantai Nirwana. Berdasarkan perhitungan kelimpahan relatif diatom epipelik yang dilakukan, spesies diatom epipelik terbanyak yang ditemukan adalah Navicula sp dan spesies yang paling sedikit jumlahnya adalah Stephanodiscus sp. Diatom epipelik yang paling banyak ditemukan jumlahnya adalah Navicula sp yakni 143 spesies, sedangkan jumlah diatom epipelik yang paling sedikit jumlahnya adalah Stephanodiscus sp sebanyak 2 spesies. Selain jumlahnya yang banyak, Navicula sp juga terdistribusi secara merata di setiap stasiun. Christiani, et al. (2017) menyatakan bahwa distribusi dan melimpahnya organisme dipengaruhi oleh kondisi air yang merupakan tempat hidupnya. Organisme yang toleran terhadap lingkungan akan mampu bertahan hidup dan melimpah jumlahnya. Martin dan Fernandez (2012) menyatakan bahwa Navicula sp terdistribusi secara luas pada semua perairan. Tingginya rentang toleransi terhadap kondisi lingkungan, karena Navicula sp memiliki tangkai berlendir, digunakan sebagai alat penempel yang kuat pada substrat sehingga dapat hidup pada perairan berarus 


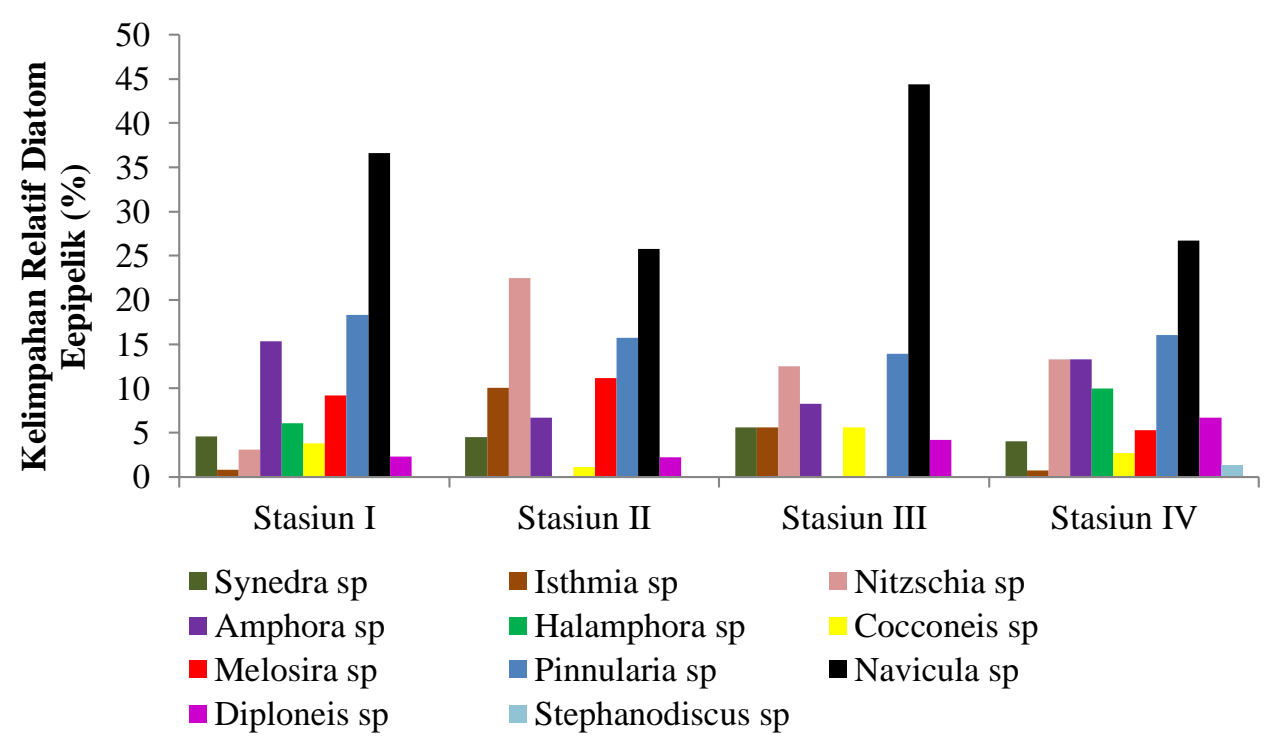

Gambar 4. Kelimpahan Relatif Diatom Epipelik Pada Masing - Masing Stasiun Pengamatan

Pengaruh Ukuran Partikel Sedimen dan Kandungan Bahan Organik Sedimen terhadap Kelimpahan Diatom epipelik

Hasil analisis regresi linier yang dilakukan dengan menggunakan software Micosoft Excel antara ukuran partikel sedimen $(\mathrm{Mm})$ dengan kelimpahan diatom epipelik di perairan Teluk Bayur diperoleh persamaan regresi $\quad \mathrm{y}=9968,1-2250,5 \mathrm{x}$. Nilai $R^{2}$ adalah 0,3437 yang artinya pengaruh ukuran partikel sedimen $(\mathrm{Mm})$ terhadap kelimpahan diatom epipelik sebesar $34,37 \%$. Sedangkan nilai $r$ yakni 0,586259, menyatakan hubungan ukuran partikel sedimen (Mm) terhadap kelimpahan diatom epipelik sedang

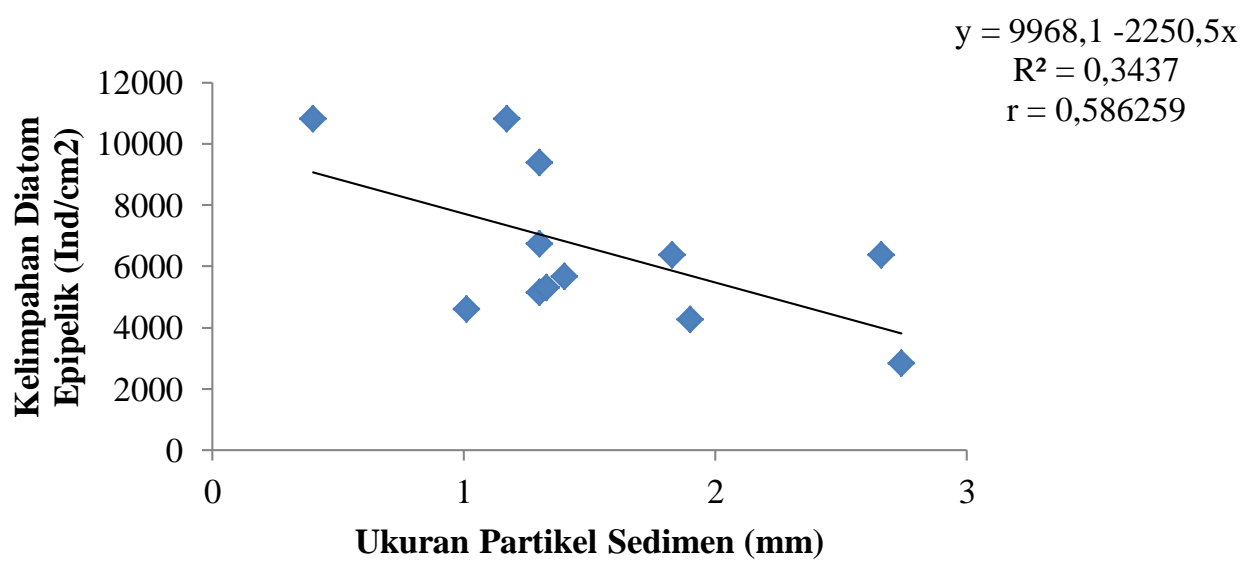

Gambar 5. Pengaruh Ukuran Partikel Sedimen (Mm) terhadap Kelimpahan Diatom Epipelik di Perairan Teluk Bayur

Sedangkan untuk hasil analisis pengaruh antara kandungan bahan organik sedimen terhadap kelimpahan diatom epipelik di perairan Teluk Bayur Sumatera Barat diperoleh persamaan regresi $\mathrm{y}=$ $462,16+1520,5 x$. Nilai $R^{2}$ yakni 0,5178 yang artinya pengaruh kandungan bahan organik sedimen terhadap kelimpahan diatom epipelik sebesar 51,78\%. Sedangkan nilai r 0,719583 , artinya hubungan antara bahan organik sedimen terhadap kelimpahan diatom epipelik kuat. 

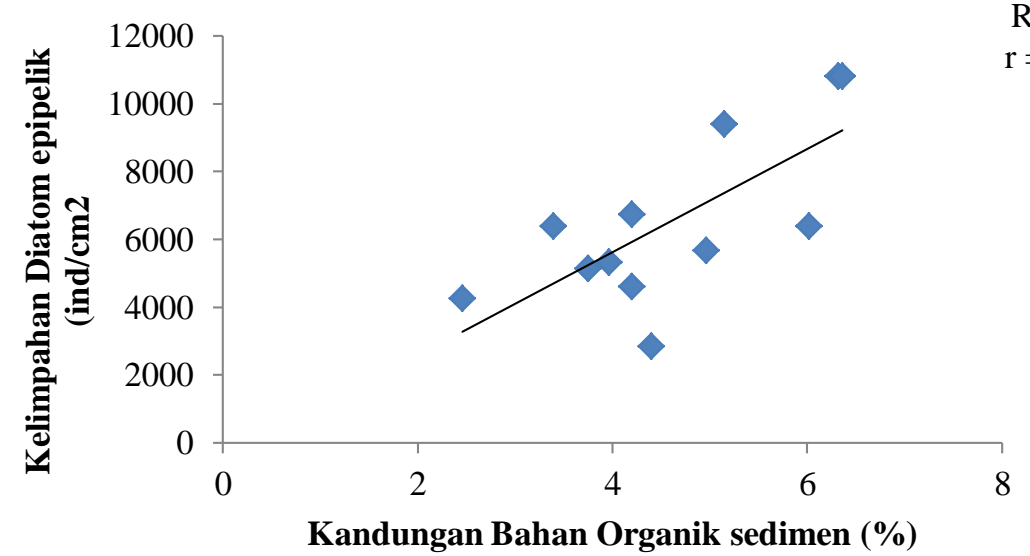

$$
\begin{gathered}
y=-462,16+1520,5 x \\
R^{2}=0,5178 \\
r=0,719583
\end{gathered}
$$

Gambar 6. Pengaruh Kandungan Bahan Organik Sedimen terhadap Kelimpahan Epipelik di Perairan Teluk Bayur

Ukuran diameter partikel sedimen yang semakin tinggi akan mempengaruhi kandungan bahan organik sedimen itu sendiri. Partikel sedimen yang lebih halus mengandung bahan organik yang lebig tinggi. Hal ini akan berpengaruh terhadap kelimpahan diatom epipelik di perairan tersebut. Semakin kecil ukuran partikel sedimen, maka kandungan bahan organik sedimen semakin besar dan kelimpahan diatom epipelik semakin tinggi. Hawari (2014) menyatakan bahwa bahan organik merupakan sumber makanan bagi biota laut yang pada umumnya terdapat pada substrat, sehingga ketergantungannya terhadap bahan organik sangat besar. Oleh sebab itu, keberadaan bahan organik penting artinya bagi kehidupan organisme bentos di sedimen. Menurut Bengen (2001), bahan organik di perairan terdapat sebagai partikel tersuspensi, bahan organik yang mengalami perubahan dan bahan organik yang berasal dari daratan dan terbawa oleh aliran sungai. Pada umumnya jenis sedimen lumpur lebih kaya akan unsur hara daripada sedimen pasir (Situmorang, 2008).

\section{KESIMPULAN DAN SARAN Kesimpulan}

Parameter kualitas perairan yang diukur di perairan tersebut tergolong kategori baik untuk pertumbuhan diatom epipelik. Tipe sedimen perairan Teluk Bayur dikelompokkan menjadi 4 jenis, yaitu kerikil (Gravel), kerikil berpasir (Sandy Gravel), pasir berkerikil (Gravelly Sand), pasir (sand). Secara keseluruhan, kondisi substrat sedimen perairan Teluk Bayur mengandung ukuran butiran yang kasar. Kandungan bahan organik di perairan tersebut dikategorikan menjadi sangat rendah hingga kategori rendah. Berdasarkan kelimpahannya, perairan tersebut digolongkan menjadi mesotrofik yang berarti kelimpahan diatom sedang. Semakin kecil ukuran partikel sedimen, maka kandungan bahan organik sedimen semakin besar dan kelimpahan diatom epipelik semakin tinggi.

Saran

Penelitian diatom epipelik ini dilakukan dengan pengambilan sampel diatom epipelik secara horizontal. Oleh karena itu diperlukan penelitian tentang kelimpahan diatom epipelik di perairan Teluk Bayur secara vertikal (per kedalaman). 


\section{DAFTAR PUSTAKA}

1. Anil, A.C dan S. Mitbavkar. (2002). Diatom of The Microphytobenthic Comunity Population Structure in a Tropical Intertidal Sand Flat. National Institute of Oeanography, Volume 140, Pages 41 - 57.

2. APHA. (1995). Standar Methods For The Examination Of Water And Wastewater. (19th ed). American Water Work Association, Water Pollution Control Federation. Washington D.C.

3. Bengen, D.G. (2001). Pedoman Teknis Pengenalan dan Pengelolaan Ekosistem Mangrove, Pusat Kajian Sumberdaya Pesisir dan Lautan. Institut Pertanian Bogor. Bogor. Indonesia.

4. Cahoon, B. dan K.A. Safi. (2002). Distribution and Biomass Of Bentic Microalgae in Manukau Harbour. The royal Society of New Zealand. New Zealand.

5. Christiani, C., A. I. Insan, dan D.S. Widyartini. 2017. Kelimpahan dan Potensi Biofuel Mikrofitobenthos dari Perairan Sungai Pekacangan yang Terkena Limbah Air Tapioka. Majalah Ilmiah BIOSFERA: A Scientific Journal. Volume 32(3), Pages 169-175.

6. Clark, R.B. (2003). Marine Pollution. Oxpord University Press. New Yorks.

7. Emiyarti. (2004). Karakteristik Fisika Kimia Sedimen dan Hubungannya dengan Struktur Komunitas Makrozoobenthos di Perairan Teluk Bayur Kendari. (p. 95) Program Pasca Sarjana. IPB. Bogor.

8. Hawari, A. (2014). Hubungan Antara Bahan Organik Sedimen dengan Kelimpahan Makroozoobenthos di Perairan Pantai Pandan Provinsi Sumatera Utara. Skripsi. Fakultas Perikanan dan Ilmu Kelautan. Universitas Riau. Pekanbaru.

9. Martin, G., and M.R. Fernandez. 2012. Diatom As Indicators of water Quality and Ecological Status: Sampling, Analysis and Some Ecological Remarks. in Voudouris (editor), Ecological Water Quality - Water Treatmentand Reuse. In Tech Europe. Croatia.

10. Nugroho, S.H. (2014). Sebaran Sedimen Berdasarkan Analisis Ukuran Butir di Teluk Weda, Maluku Utara. Jurnal Ilmu Pertanian Indonesia. Volume 1(6), Pages 229 - 240

11. Nybakken, J.W. (1992). Biologi Laut Suatu Pendekatan Ekologi. PT. Gramedia Jakarta.

12. Rifardi. (2001). Study on Sedimentology From The Sungai Mesjid Estuary and Its Environs in the Rupat Strait, The East Coast of Sumetera Island. Journal of Coastal Development. Volume 4(2), Pages 87-97.

13. Rifardi. $\left(2008^{\mathrm{a}}\right)$. Tekstur Sedimen- Sampling dan Analisis. Pekanbaru: UNRI Press.

14. _ $\left(2008^{\mathrm{b}}\right)$. Deposisi Sedimen di Perairan Laut Dangkal. Ilmu Kelautan. Indonesia Journal of Marine Sciences, Volume 13(3), Pages 147-152.

15. Supono. (2008). Analisis Indeks True Diversitas Diatom Eipelic Tambak Udang dengan Tekstur Tanah yang Berbeda. Maspari Journal, Volume 8(1), Pages 31-38.

16. Supriyadi, S. (2008). Kesuburan Tanah Lahan Kering Madura. Embryo. Volume 5(2), Pages $124-131$.

17. Suwartimah, K., W. Widianingsih, R. Hartati, dan S.Y. Wulandari. (2012). Komposisi Jenis dan Kelimpahan Diatom Bentik di Muara Sungai Comal Baru Pemalang. Ilmu Kelautan: Indonesian Journal of Marine Sciences, Volume 16(1), Pages 16-23. 